UDC 94(510): 329.15(510)

\title{
THE IDEOLOGY OF THE CHINESE COMMUNIST PARTY IN THE PERIOD OF THE REFORMS AND OPENING-UP: THE PROBLEM OF DEFINITION AND RESEARCH METHODOLOGY
}

\author{
V. Kiktenko \\ Dr. Habil. in Philosophy, Senior Fellow \\ A. Krymskyi Institute of Oriental Studies, NAS of Ukraine \\ 4, Hrushevskoho Str., Kyiv, 01001, Ukraine \\ kiktenko@gmail.com
}

The article studies the problem of definition and methods of studying the ideology of the Chinese Communist Party in the post-Maoist period, provides a comparative analysis of these approaches. The author analyses the "official ideology" concept of the CCP and its various expressions in the political theories of the Chinese leaders, which are generally subordinated to the single task of building the Socialism with Chinese Characteristics. The next point deals with the importance of studying the ideology of the CPC since it is simultaneously a theory of cognition of the world (epistemology) and political action (legitimacy in society). Therefore, the study of the ideology of the CPC is the main approach not only to understand the party's strategy and change of its leadership, but also to analyze the political and socio-economic development of the PRC as a whole. The research highlights that in existing studies insufficient attention is paid to the study of the holistic development of the official ideology of the CCP in the genesis and in various contexts (internal and external). Accordingly, this determines the need for a systematic study of the ideology of the CCP, represented in genetically linked party concepts - Marxism-Leninism, the ideas of Mao Zedong, the Deng Xiaoping theory, the concept of Three Represents (Jiang Zemin Theory), Hu Jintao's Scientific Outlook on Development and Xi Jinping's ideas about Socialism with Chinese Characteristics for a New Era. It is noted that new concepts in the ideology of the CCP not only determine the political future of China, but also have great international influence, that accordingly defines the relevance of research in this area. Particular attention is paid to the formation of various approaches to understanding the ideology of the CCP, starting with the work of the American sociologist and historian F. Schurmann. It is proved the fallacy of the point of view quite widespread among Western scholars that in modern China, ideology is a dogma and performs only the function of deterrence in the implementation of social and economic reforms. It is shown that ideology still plays a decisive role in the PRC, and this is achieved due to the high degree of adaptation of theories and party language. It is determined that further studies of the development of official ideology should be aimed at creating an overall picture of the political transformations of the CPC.

Keywords: ideology, Marxism-Leninism, CCP, the ideas of Mao Zedong, Deng Xiaoping theory, Three Represents, The Scientific Outlook on Development, Socialism with Chinese Characteristics, Socialism with Chinese Characteristics for a New Era, post-communism, post-Marxism, post-Maoism

(C) 2020 V. Kiktenko; Published by the A. Yu. Krymskyi Institute of Oriental Studies, NAS of Ukraine and the Ukrainian Association of Sinologists on behalf of The Chinese Studies. This is an Open Access article distributed under the terms of the Creative Commons Attribution License (https://creativecommons.org/licenses/by-nc-nd/4.0/). 


\section{ІДЕОЛОГІЯ КОМУНІСТИЧНОЇ ПАРТІЇ КИТАЮ В ПЕРІОД ПОЛІТИКИ РЕФОРМ І ВІДКРИТОСТІ: ПРОБЛЕМА ВИЗНАЧЕННЯ ТА МЕТОДОЛОГІЯ ДОСЛІДЖЕНЬ}

\section{B. О. Кіктенко}

Ідеологія Комуністичної партії Китаю та різні контексти іiї розвитку постійно перебувають у центрі уваги істориків, політологів, філософів, лінгвістів, китаєзнавців, хоча найчастіше об'єктом дослідження є не сама ідеологія, а суміжні питання, що стосуються історії та сучасного розвитку Китайської Народної Республіки. Багато в чому це пояснюється тим, що ідеологія в КНР одночасно є теорією пізнання світу (епістемологія) і політичною дією (легітимність у суспільстві). Тому вивчення ідеології КПК є основним підходом не тільки для розуміння стратегії партії та зміни ії керівництва, а й для аналізу політичного та соціально-економічного розвитку КНР в цілому. При цьому багатогранність поняття “ідеологія", відсутність єдиного визначення поняття “ідеологія КПК”, різно-дисциплінарні дослідження загалом ускладнюють прояснення цього питання. Найчастіше роботи, присвячені ідеології КПК, зосереджені на питаннях існування режиму влади, державному управлінні, механізмах і ефективності проведених реформ на тому чи іншому історичному етапі. Менше уваги приділяється вивченню цілісного розвитку офіційної ідеології КПК в генезі й у різних контекстах (внутрішніх і зовнішніх). Це визначає необхідність системного вивчення ідеології КПК, представленої в генетично пов'язаних партійних концепціях - марксизм-ленінізм, ідеї Мао Цзедуна (毛 泽东思想 Mao Zedong sixiang), теорія Ден Сяопіна (邓小平理论 Deng Xiaoping lilun), концепція “трьох представництв” Цзян Цземіня (三个代表重要思想 san ge daibiao zhongyao sixiang), “наукова концепція розвитку” Ху Цзіньтао (科学 发展观 kexиe fazhan guan) та ідеї Сі Цзіньпіна про “соціалізм із китайською специфікою в нову епоху” (新时代中国特色社会主义 xin shidai zhongguo tese shehui zhuyi). Безумовно, що нові концепти в ідеології КПК не тільки визначатимуть політичне майбутнє Китаю, але і матимуть великий міжнародний вплив, що, відповідно, визначає і актуальність досліджень у цій сфері. Мета полягає у вивченні процесів формування нових концептів ідеології КПК, включаючи витоки комуністичного правління і шляхи переходу в посткомуністичне суспільство. Джерельною базою дослідження ідеології КПК є емпіричні дані (тексти робіт, виступів, інтерв’ю партійних лідерів) і теоретичні ідеї провідних вчених у сфері вивчення ідеології сучасного Китаю.

Саме по собі поняття "ідеологія" є одним із найскладніших, яке отримало цілу низку визначень в історії гуманітарних і соціальних наук. Як відомо, сам термін “ідеологія” був введений у Франції наприкінці XVIII ст. А. Дестюта де Трасі з метою створення науки про загальні принципи формування ідей i основи людського знання. Оскільки це вчення мало виступати основними принципами для керівництва як у науці, так і в соціальному житті, то відповідно Дестют де Трасі бачив у ідеології систему знань першооснов моралі, політики, права. Була зроблена спроба об'єднати раціональність із чуттєвим досвідом і створити концептуальну систему, звільнену від ідеологічних обмежень, нав'язаних метафізикою. Однак ця прогресивна ідеологія спочатку була відкинута Наполеоном Бонапартом, а потім піддана критиці К. Марксом, який дав визначення ідеології як “помилкової свідомості”, показавши таким чином iï негативну конотацію. За Марксом, ідеологія відображає набір помилкових 
ідей, які приховують соціальні протиріччя, спотворюють реальне життя та історичний процес розвитку людини. Звідси робився висновок, що ідеологія це система мислення, яку панівний клас створив для підтримки своїх інтересів і зміцнення заведеного політичного порядку.

Під впливом робіт К. Маркса в науковому середовищі сформувалося два напрямки розуміння ідеології-марксистське та немарксистське. Для марксистського спрямування притаманний акцент на відносинах між економічним базисом і надбудовою, взаємодією і діалогом. Так, наприклад, для Леніна революційна ідеологія - це мова революційного класу, а не помилкова свідомість; це інструмент класової боротьби. Потім "революційна ідеологія" стала одним із центральних понять марксистського спрямування (А. Грамші, Л. Альтюсер, Д. Лукач та ін.). У немарксистському напрямку слід перш за все виділити німецького та британського філософа К. Мангайма, який у своїй соціології знання особливу увагу приділив аналізу ідеології. Згідно з Мангаймом, будь-яка думка і концепція обмежені певними соціальними та історичними умовами, i тому вони неминуче матимуть свої власні характерні особливості та упередження: «У слові “ідеологія" імпліцитно міститься розуміння того, що в певних ситуаціях колективне несвідоме певних груп приховує дійсний стан суспільства як від себе, так і від інших, тим самим стабілізуючи його» [Манхейм 2010, 7]. Тобто ідеологія - це упереджене відображення соціальної дійсності, що виражає інтереси певних груп або класів, які перебувають при владі й, відповідно, прагнуть зберегти існуючий порядок речей; протиставляється утопії як потенційній ідеології в цьому сенсі. У цілому існує широкий спектр визначень ідеології в немарксистському напрямку з різних філософських позицій. Наприклад, французький філософ П. Рікер, який особливу увагу приділив роботам К. Мангайма [Ricoeur 1986], розуміє ідеологію з точки зору герменевтики і соціальної інтеграції, і тому ідеологічна критика - це нескінченна робота [Ricoeur 1981, 225-227].

У дослідженнях КПК ідеологія посідає важливе місце, що має особливе значення для розуміння історії розвитку комуністичного руху в Китаї та в світі перш за все в 1960-ті pp. Тут особливе місце займає книга американського соціолога та історика Ф. Шурмана "Ідеологія та організація в комуністичному Китаї” [Schurmann 1966]. У цій роботі була сформульована концепція “організаційної ідеології” і показаний процес формування під іiї впливом мережі організацій, що охопили всі верстви китайського суспільства починаючи 3 1930-х pp. [Schurmann 1966, 18]. Ф. Шурман визначив ідеологію КПК як “організаційну ідеологію" та розділив іiі на два важливих компоненти - "чиста ідеологія” і “практична ідеологія”. Відповідно до цього підходу, всі думки і концепції в кінцевому підсумку призводять до результатів певних дій, але при цьому немає прямого та детермінованого зв'язку між “ідеєю” і “дією” [Schurmann 1966, 21]. Звідси робиться висновок, що “чиста ідеологія" $є$ похідною від теорії (марксизм-ленінізм та ідеї Мао Цзедуна), а “практична ідеологія" це поєднання чистої ідеології та дії [Schurmann 1966, 23]. Структура аналізу “організаційної ідеології” Ф. Шурмана в основному визначає ідеологічні характеристики організації, яка встановлює систематичну дослідницьку спрямованість пізнання та інтерпретації того, як аналізувати мислення та дії членів КПК. Такий підхід дозволяє не тільки пояснити різні значення ідеології в конотації, але також аналізувати зміну значень ідеології в процесі розвитку з точки зору конкретних політичних моделей поведінки. У цілому підхід Ф. Шурмана став відправною точкою в дослідженнях ідеології КПК. 
Період наприкінці 1980-х - на початку 1990-х рр. ознаменував собою крах Світової системи соціалізму, що на той час перш за все в країнах Західного світу і Західного вибору розумілося як тріумф лібералізму, що найбільш чітко було висловлено в книзі американського філософа і політолога Ф. Фукуями "Кінець історії та остання людина" [Fukuyama 1992]. Заявлений кінець протистояння ідеологій, відповідно, стверджував і остаточну перемогу лібералізму як панівної глобальної ідеології. Однак понад два десятиліття потому стало зрозуміло, що ці твердження не відповідають посткомуністичній реальності, і одним із найбільш яскравих прикладів тут є нові ідеологічні концепції ідеологій КПК. Сьогодні той же самий Ф. Фукуяма розмірковує про сильні й слабкі сторони “китайської моделі", яку він визначає в якості орієнтира для інших політичних систем у Східній Азії: демократії в Японії, Південній Кореї і на Тайвані оцінюються ним не стільки в порівнянні з іншими демократіями світу, скільки з авторитарною системою та економічним успіхом централізованої моделі розвитку Китаю. 3 новою силою розгорілися наукові дискусії про довгострокову перспективу розвитку державної системи КНР і навіть про можливо більш ефективну модель управління, яка не базується на цінностях західної демократії.

Досить поширеною серед західних вчених є точка зору, що в сучасному Китаї ідеологія є догмою і виконує тільки функцію стримування при здійсненні соціально-економічних реформ. Такий підхід також передбачає, що ідеологічні концепції принципово застаріли і не мають ніякого значення для суспільного життя. Згідно з іншим підходом, якого дотримується і автор цієї статті, ідеологія, як і раніше, відіграє визначальну роль у КНР, і це досягається завдяки високому ступеню адаптованості теорій та мови партії. Політична ідеологія в сучасному Китаї грає вирішальну роль у підтримці згуртованості партії і народної легітимності КПК, яка доклала величезних зусиль для переосмислення своїх ідеологічних дискурсів. Всі вищі керівники Китаю надавали великого значення ідеології, про що можна дізнатися з робіт Мао Цзедуна [毛澤東 1991], Ден Сяопіна [邓小平 1989], Цзян Цземіня [江泽民 2001], Ху Цзіньтао [中共中央... 2006], а сьогодні на це звертає увагу й нинішній Голова КНР і Генеральний секретар КПК Сі Цзіньпін [习近平 2013]. На відміну від посткомуністичних держав Центральної та Східної Свропи, а також Росії, в КНР керівною партією залишається КПК, яка ніколи офіційно не засуджувала марксизм-ленінізм і, відповідно, сповідує комуністичну ідеологію. Незважаючи на більш прагматичну і раціональну Політику реформ і відкритості, ідеологія залишається в центрі політичної системи КНР. Однак чотири десятиліття здійснення глибоких соціально-економічних реформ, в яких використовуються ринкові механізми, і зростання міжнародної економічної інтеграції фактично поклали край плановій економіці і спільному проекту побудови комунізму в найближчому майбутньому. У результаті, марксизм-ленінізм був значно змінений і адаптований відповідно до китайського контексту, й тому нові концепти офіційної ідеології КПК в цілому це не тільки комуністичний, а й китайський продукт (马克思主义的中国化 makesi zhuyi de zhongguo hua). Відзначимо, що є невелика кількість праць, присвячених вивченню означеного питання, й, відповідно, цей напрямок досліджень ще перебуває на початковому етапі [Chen Cheng 2016; Chen Cheng 2007; Ding 1995; Gries 2004; Holbig 2018; Кіктенко 2015; Кіктенко 2016 та ін.].

“Офіційна ідеологія” як особлива політична ідеологія використовується членами правлячих груп або організацій, є частиною системи переконань і цінностей політичної системи, служить зовнішнім чином для презентації країни в 
світі. Такі відомі західні марксисти, як А. Грамші та Л. Альтюсер вказують на важливу функцію “офіційної ідеології” в управлінні країною, підтримці існуючого політичного і соціального порядку. Крім того, “офіційна ідеологія" впливає на формування народного світогляду, який служить основою для підтримки легітимності влади і консолідації політичних сил. Тому аналіз “офіційної ідеології" останнім часом все частіше використовується в роботах, присвячених вивченню конкретної політичної ідеології і ії значення в питаннях державного управління.

При вивченні безпосередньо офіційної ідеології КПК, по-перше, аналізуються ідеї, методи переконання, самосвідомість та цінності влади і, по-друге, ідеї та пропозиції, висунуті окремими особами і групами, які не займають офіційні позиції в країні або не мають реальної політичної влади. У широкому сенсі “офіційна ідеологія КПК” - це домінуюча ідеологія всередині партії, а у вузькому сенсі - це домінуючі ідеї та концепти, прийняті "істеблішментом” і політичними лідерами партії. Таким чином, “офіційна ідеологія КПК” включає в себе всі можливі ідейні розбіжності політичної еліти КПК, i, відповідно, аналіз “офіційної ідеології КПК” спрямований на всі ідеології, які генеруються всередині партії, бо вони по своїй суті взаємопов'язані теоретично (традиціоналізм, марксизм-ленінізм, маоїзм) та історично (внутрішньопартійна боротьба за владу, “ліві” та “праві”). Крім того, офіційна ідеологія КПК також $є$ сполучною ланкою між державою й суспільством, що має важливе значення для формування структури публічного дискурсу, який в свою чергу впливає на соціальний консенсус, консолідацію політичного порядку, стандартизацію політичної поведінки мас і прийняття цінностей. Вивчення цих аспектів стало важливим напрямком у дослідженнях офіційної ідеології КПК зокрема і політичного розвитку КНР в цілому. Важливо також відзначити, що в КНР національна ідеологія, ідеологія офіційної влади і партійна ідеологія концептуально збігаються. Що ж стосується загального визначення “офіційної ідеології КПК”, то під нею розуміють набір внутрішньопартійних ідеологічних і теоретичних систем, спрямованих на пояснення і забезпечення політичного, соціально-економічного та культурного розвитку КНР. Дослідження розвитку офіційної ідеології спрямовано на створення загальної картини політичних трансформацій КПК. Як приклад вивчення офіційної ідеології КПК можна навести роботу К. Місра "Від постмаоїзму до постмарксизму: розмивання офіційної ідеології в Китаї Ден Сяопіна”, в якій автор досліджує інтелектуальні дискусії кінця 1970-х - 1980-х pp. [Misra 1998].

Формування нових ідеологій у Китаї почалося ще в XIX ст. і обумовлювалося насамперед цивілізаційним зіткненням із провідними країнами Заходу i необхідністю здійснення модернізації. У цей час імператорський Китай терпить ряд серйозних військових поразок під час двох Опіумних воєн (18401842, 1856-1860). Як наслідок, у середині XIX - на початку XX ст. Китай був змушений під тиском більш потужної економічної та військової сили підписати з низкою європейських держав, США і Японією так звані “нерівноправні договори” (不平等条约 bupingdeng tiaoyue). Загальновідомо, що в традиційному Китаї офіційна ідеологія протягом багатьох століть була синоцентричною, що знайшло вираження у відповідних концептах - “піднебесна" (天下 tianxia), “небесна династія/імперія" (天朝 tianchao), “серединна держава” (中国 zhongguo), “квітуча серединна держава” (中华 zhonghua), а також пов'язані з ними “модель допоміжної держави” (辅国 fuguo) і конфуціанський ідеал досконалого суспільства (大同 datong). Під потужним силовим впливом Західної цивілізації 
Китай сприйняв Вестфальську систему міжнародних відносин національних держав. Це також вплинуло на пошуки власної моделі розвитку, що в першій половині XX ст. переважно визначалося китайською націоналістичною ідеєю партії Гоміньдан, а з 1949 р. в утвореній Китайській Народній Республіці послідовно визначальними були ідеї марксизму-ленінізму і Мао Цзедуна, теорія Ден Сяопіна, концепція “трьох представництв” Цзян Цземіня, “наукова концепція розвитку” Ху Цзіньтао та ідеї Сі Цзіньпіна про “соціалізм із китайською специфікою нової епохи".

Спочатку офіційна ідеологія КПК була натхненна успіхами Радянського Союзу і, відповідно, формувалася в рамках марксизму-ленінізму, спрямованого на побудову соціалізму. Але саме практичні завдання привели до того, що КПК відійшла від досвіду СРСР і міжнародного комуністичного руху й створила власну офіційну ідеологію. Ї̈̈ специфікою стало те, що теорія марксизмуленінізму була доповнена практикою китайської революції, яка мала суттєві відмінності (насамперед іiі селянський характер, а не пролетарський). Досить швидко почалася “китаїзація” марксизму, що стало визначальним моментом у подальшому формуванні офіційної ідеології КНР. Відхід від ортодоксальної радянської ідеології був пов'язаний із бажанням китайського партійного керівництва вийти з-під контролю СРСР, бо це дуже нагадувало недавнє минуле, в якому Китай перебував під тиском країн Заходу. Після більш ніж десятирічної співпраці з Комуністичним Інтернаціоналом Мао Цзедун вирішив створити свою версію комуністичної ідеології в Китаї й зробив сильний акцент на революційній складовій (Великий стрибок, Культурна революція). У постмаоїстський період із початком запровадженої Ден Сяопіном Політики реформ і відкритості, а також потім при Цзян Цземіні, Ху Цзіньтао і Сі Цзіньпіні в основу було покладено ідею побудови “соціалізму з китайською специфікою” (中国特色社会主义 zhongguo tese shehui zhuyi).

У постмаоїстський період (Політика реформ і відкритості, 改革开放 gaige kaifang) істотно змінилася офіційна ідеологія КПК, що, на думку К. Брауна і Лі Цюань, свідчить про перехід Китаю на етап "посткомуністичного суспільства", для якого характерний прагматизм у сфері ідеології [Brown 2012; Li Quan 2017]. Відповідно до цього підходу, що сформувався в 1990-і рр., китайський матеріальний прагматизм сконцентрований на розвитку продуктивних сил (економічна модернізащія), і це $\epsilon$ центральним елементом соціалістичної модернізації. Таким чином з'явилася нова редакція ідеології марксизму-ленінізму 3 китайською специфікою - здійснення фундаментальної реформи економіки шляхом усунення перешкод для розвитку продуктивних сил за умови збереження і поліпшення соціалістичної ринкової економіки. Це вказує на переорієнтацію ідеологічної дискусії всередині КПК, яка, важливо особливо відзначити, ніколи не припинялася. Таким чином, йдеться не про занепад комуністичної ідеології в Китаї, а про спроби реагування на нові виклики, які постали перед партією і урядом Китаю. Нові концепти офіційної ідеології КПК були сформовані й продовжують формуватися в рамках цілей і завдань побудови соціалізму з китайською специфікою, а їхні відмінні риси швидше визначаються спрямованістю і формою реалізації. На проблему визначення “офіційної ідеології” Д. Міерзеєвський і Б. Ковальський дивляться ширше і стверджують, що “...китайську специфіку слід розуміти як трійцю культури і цивілізації, антиімперіалістичний опір, заснований на ідеологічних передумовах справедливості й рівного матеріального статусу, і державну ідентичність, яка визнається через формування кордонів і ефективне управління" [Mierzejewski 2019, 4]. 
Хоча офіційна ідеологія КНР в своїй основі залишається незмінною з часів маоїзму, проте з 1978 р., з початком періоду Політики реформ і відкритості, були сформульовані й нові ідеологічні концепти для подолання явних невідповідностей між ідеями марксизму-ленінізму та Мао Цзедуна й реальністю, що насамперед виразилося у відмові від будівництва комунізму, використанні ринкових механізмів та участі в глобальній економіці [Chen Cheng 2007, 278]. Відбувся відхід від двох фундаментальних ленінських принципів, що характеризують всі комуністичні режими: централізованої планової економіки (або економіки адміністративно-командного типу) і зняття класових обмежень на членство в КПК, що і дає підставу класифікувати Китай як “посткомуністичний” із сильним акцентом в ідеології на прагматизмі. Конкретні зміни в ідеології були виражені в теорії Ден Сяопіна, концепції “трьох представництв" Цзян Цземіня, “науковій концепції розвитку” Ху Цзіньтао, ідеях Сі Цзіньпіна про "соціалізм із китайською специфікою в нову епоху" і так званому Пекінському консенсусі (“Китайська економічна модель”, 中国模式 Zhongguo moshi), який хоч і не використовується китайським керівництвом, але увійшов у науковий обіг для визначення політичного і соціально-економічного розвитку Китаю в постмаоїстський період. Загалом для нової офіційної ідеології КПК притаманний прагматичний еклектизм, що дає необхідну гнучкість у розробці тих чи інших політичних питань і сприяє досягненню стабільності влади (китайський варіант авторитарного капіталізму). У цілому успішність нових концептів офіційної ідеології в посткомуністичний період залежить від здатності влади узгодити їх із базовими ідеологічними концептами КНР. Іншими словами, КПК використовує офіційну ідеологію для перегляду визначення соціалізму, підтримки консенсусу між партійними лідерамиреформаторами і лідерами-консерваторами.

Таким чином, при вивченні ідеології КПК необхідно враховувати широке коло питань із точки зору міждисциплінарного підходу. Особливу увагу необхідно приділяти взаємозалежності між ідеологією і владою, а також можливим інтерпретаціям концепту “офіційна ідеологія КПК”. Також важливо враховувати, що в сучасному Китаї не тільки держава, а й суспільство впливає на формування ідеології. 3 цієї причини системне дослідження офіційної ідеології КПК є важливим елементом в аналізі розвитку сучасного соціально-економічного і політичного розвитку КНР. На основі проведеного в пропонованій роботі аналізу можна зробити висновок про те, що офіційна ідеологія КПК в своїй основі $є$ марксистсько-ленінською, але з початком Політики реформ і відкритості вона стала розвиватися в якості системи інтерпретацій "соціалізму з китайською специфікою”. Ця нова офіційна ідеологія використовується партійним керівництвом для досягнення загальних цілей партійного будівництва, розвитку країни і загального процвітання нації.

\section{ЛІТЕРАТУРА}

Кіктенко В. О. "Китайська мрія” як теорія нового етапу модернізації КНР // Східний світ, 2015, № 3.

Кіктенко В. О. Від революції до модернізації: стратегія та ідеологія КНР періоду реформ // Східний світ, 2016, № 1.

Манхейм К. Избранное: Диагноз нашего времени. Москва, 2010.

Brown K. The Communist Party of China and Ideology // China: An International Journal, 2012, Vol. 10, No. 2.

Chen Cheng, Sil R. Stretching Postcommunism: Diversity, Context, and Comparative Historical Analysis // Post-Soviet Affairs, 2007, Vol. 23, No. 4. 
Chen Cheng. The Return of Ideology: The Search for Regime Identities in Postcommunist Russia and China. Ann Arbor, 2016.

Ding X. L. The Decline of Communism in China: Legitimacy Crisis, 19771989. Cambridge, New York, 1995.

Fukuyama F. The End of History and the Last Man. Toronto, New York, 1992. Gries $P$. H. China's New Nationalism: Pride, Politics, and Diplomacy. Berkeley, 2004.

Holbig $H$. China after Reform: The Ideological, Constitutional, and Organisational Makings of a New Era // Journal of Current Chinese Affairs, 2018, Vol. 47, No. 3.

Li Quan. The idea of governance and the spirit of Chinese neoliberalism. New York, 2017.

Mierzejewski D., Kowalski B. China's Selective Identities state, ideology and culture. Hampshire, 2019.

Misra K. From post-Maoism to post-Marxism: the erosion of official ideology in Deng's China. New York, 1998.

Ricoeur P. Hermeneutics and the human sciences: essays on language, action, and interpretation. New York, Paris, 1981.

Ricoeur P. Lectures on Ideology and Utopia. New York, 1986.

Schurmann F. Ideology and organization in Communist China. Berkeley, 1966. 邓小平. 在接见首都戒严部队军以上干部时的讲话 // 期刊论文, 1989, № 5.

江泽民. 论党的建设. 北京, 2001 .

毛澤東. 毛澤東選集第二卷. 北京, 1991.

习近平. 习近平：胸怀大局把握大势着眼大事 努力把宣传思想工作做得 更好, 2013年08月21, available at: http://cpc.people.com.cn/n/2013/0821/c6409422636876.html (accessed 8 April 2020).

中共中央文献研究室. 十六大以来重要文献选遍-中. 北京, 2006.

\section{REFERENCES}

Kiktenko V. O. (2015), “'Kytays'ka mriya' yak teoriya novoho etapu modernizatsiyi KNR”, Skhidnyy svit, No. 3, pp. 106-14. (In Ukrainian).

Kiktenko V. O. (2016), "Vid revolyutsiyi do modernizatsiyi: stratehiya ta ideolohiya KNR periodu reform", Skhidnyy svit, No. 1, pp. 83-93. (In Ukrainian).

Mankheym K. (2010), Izbrannoye: Diagnoz nashego vremeni, RAO Govoryashchaya kniga, Moskva. (In Russian).

Brown K. (2012), "The Communist Party of China and Ideology", China: An International Journal, Vol. 10, No. 2, pp. 52-68.

Chen Cheng, Sil R. (2007), "Stretching Postcommunism: Diversity, Context, and Comparative Historical Analysis," Post-Soviet Affairs, Vol. 23, No. 4, pp. 275-301.

Chen Cheng (2016), The Return of Ideology: The Search for Regime Identities in Postcommunist Russia and China, University of Michigan Press, Ann Arbor.

Ding X. L. (1995), The Decline of Communism in China: Legitimacy Crisis, 1977-1989, Cambridge University Press, Cambridge, New York.

Fukuyama F. (1992), The End of History and the Last Man, Free Press, New York; Maxwell Macmillan, Toronto; Maxwell Macmillan International, New York.

Gries P. H. (2004), China's New Nationalism: Pride, Politics, and Diplomacy, University of California Press, Berkeley.

Holbig H. (2018), "China after Reform: The Ideological, Constitutional, and Organisational Makings of a New Era", Journal of Current Chinese Affairs, Vol. 47, No. 3, pp. 187-207. 
Li Quan (2017), The idea of governance and the spirit of Chinese neoliberalism, Springer Berlin Heidelberg, New York, NY.

Mierzejewski D., Kowalski B. (2019), China's Selective Identities state, ideology and culture, Palgrave Macmillan, Basingstoke, Hampshire.

Misra K. (1998), From post-Maoism to post-Marxism: the erosion of official ideology in Deng's China, Routledge, New York.

Ricoeur P. (1981), Hermeneutics and the human sciences: essays on language, action, and interpretation, Cambridge [Eng.], Cambridge University Press, New York, Editions de la Maison des sciences de l'homme, Paris.

Ricoeur P. (1986), Lectures on Ideology and Utopia, Columbia University Press, New York.

Schurmann F. (1966), Ideology and organization in Communist China, University of California Press, Berkeley.

Deng Xiaoping (1989), "Zai jiejian shoudu jieyan budui jun yi shang ganbu shi de jianghua", Qikan lunwen, №5, 页 5-8. (In Chinese).

Jiang Zemin (2001), Lun dang de jianshe, Zhongyang wenxian chubanshe, Beijing. (In Chinese).

Mao Zedong (1991), Mao Zedong xuanji di er juan, Min chubanshe, Beijing. (In Chinese).

Xi Jinping (2013), "Xi Jinping: Xionghuai daju bawo dashi zhuoyan dashi nuli ba xuanchuan sixiang gongzuo zuo de geng hao", 2013 nian, 08 yue 21, available at: http://cpc.people.com.cn/n/2013/0821/c64094-22636876.html (accessed 8 April 2020). (In Chinese).

Zhonggong zhongyang wenxian yanjiu shi (2006), Shilii da yilai zhongyao wenxian xuan bian-zhong, Zhongyang wenxian chuban she, Beijing. (In Chinese).

\section{ІДЕОЛОГІЯ КОМУНІСТИЧНОЇ ПАРТІЇ КИТАЮ В ПЕРІОД ПОЛІТИКИ РЕФОРМ І ВІДКРИТОСТІ: ПРОБЛЕМА ВИЗНАЧЕННЯ ТА МЕТОДОЛОГІЯ ДОСЛІДЖЕНЬ}

\section{В. О. Кіктенко}

У статті досліджуються проблема визначення та методи вивчення ідеології Комуністичної партії Китаю в постмаоїстський період, дається порівняльний аналіз цих підходів. Проаналізовано концепт “офіційна ідеологія" КПК та його різні вирази в політичних теоріях китайських лідерів, які в цілому підпорядковані єдиному завданню побудови “соціалізму з китайською специфікою". Відзначена важливість вивчення ідеології КПК, оскільки вона одночасно $є$ теорією пізнання світу (епістемологія) і політичною дією (легітимність у суспільстві). Тому вивчення ідеології КПК є основним підходом не тільки для розуміння стратегії партії та зміни ії керівництва, а й для аналізу політичного та соціально-економічного розвитку КНР в цілому. Наголошено на тому, що в існуючих дослідженнях недостатньо уваги приділяється вивченню цілісного розвитку офіційної ідеології КПК в генезі й у різних контекстах (внутрішніх і зовнішніх). Відповідно, це визначає необхідність системного вивчення ідеології КПК, представленої в генетично пов'язаних партійних концепціях - марксизм-ленінізм, ідеї Мао Цзедуна, теорія Ден Сяопіна, концепція “трьох представництв” Цзян Цземіня, “наукова концепція розвитку” Ху Цзіньтао та ідеї Сі Цзіньпіна про “соціалізм із китайською специфікою в нову епоху”. Відзначено, що нові концепти в ідеології КПК не тільки визначатимуть політичне майбутнє Китаю, але і матимуть великий міжнародний вплив, що, відповідно, визначає і актуальність досліджень у цій сфері. Особливу увагу приділено формуванню різних підходів до розуміння ідеології КПК, починаючи з роботи американського соціолога та історика Ф. Шурмана. Доведено помилковість досить поширеної серед західних вчених точки зору, що в сучасному Китаї ідеологія є догмою і виконує тільки функцію стримування при 
здійсненні соціально-економічних реформ. Показано, що ідеологія, як і раніше, відіграє визначальну роль у КНР, і це досягається завдяки високому ступеню адаптованості теорій та мови партії. Визначено, що подальші дослідження розвитку офіційної ідеології мають бути спрямовані на створення загальної картини політичних трансформацій КПК.

Ключові слова: ідеологія, марксизм-ленінізм, КПК, ідеї Мао Цзедуна, теорія Ден Сяопіна, “три представництва", “наукова концепція розвитку”, “соціалізм із китайською специфікою”, “соціалізм із китайською специфікою в нову епоху”, посткомунізм, постмарксизм, постмаоїзм

\section{ИДЕОЛОГИЯ КОММУНИСТИЧЕСКОЙ ПАРТИИ КИТАЯ В ПЕРИОД ПОЛИТИКИ РЕФОРМ И ОТКРЫТОСТИ: ПРОБЛЕМА ОПРЕДЕЛЕНИЯ И МЕТОДОЛОГИЯ ИССЛЕДОВАНИЙ}

\section{В. А. Киктенко}

В статье исследуются проблема определения и методы изучения идеологии Коммунистической партии Китая в постмаоистский период, дается сравнительный анализ этих подходов. Проанализированы концепт “официальная идеология” КПК и его различные выражения в политических теориях китайских лидеров, которые в целом подчинены единой задаче построения “социализма с китайской спецификой”. Отмечена важность изучения идеологии КПК, поскольку она одновременно является теорией познания мира (эпистемология) и политическим действием (легитимность в обществе). Поэтому изучение идеологии КПК является основным подходом не только для понимания стратегии партии и смены ее руководства, но и для анализа политического и социально-экономического развития КНР в целом. Отмечено, что в существующих исследованиях недостаточно внимания уделяется изучению целостного развития официальной идеологии КПК в генезисе и в различных контекстах (внутренних и внешних). Соответственно, это определяет необходимость системного изучения идеологии КПК, представленной в генетически связанных партийных концепциях - марксизм-ленинизм, идеи Мао Цзэдуна, теория Дэн Сяопина, концепция “трех представительств” Цзян Цзэминя, “научная концепция развития” Ху Цзиньтао и идеи Си Цзиньпина о “социализме с китайской спецификой в новую эпоху”. Отмечено, что новые концепты в идеологии КПК будут не только определять политическое будущее Китая, но и иметь большое международное влияние, что, соответственно, определяет и актуальность исследований в данной области. Особое внимание уделено формированию различных подходов к пониманию идеологии КПК, начиная с работы американского социолога и историка Ф. Шурмана. Доказано ошибочность достаточно распространенной среди западных ученых точки зрения, что в современном Китае идеология является догмой и выполняет только функцию сдерживания при осуществлении социально-экономических реформ. Показано, что идеология по-прежнему играет определяющую роль в КНР, и это достигается благодаря высокой степени адаптированности теорий и языка партии. Определено, что дальнейшие исследования развития официальной идеологии должны быть направлены на создание общей картины политических трансформаций КПК.

Ключевые слова: идеология, марксизм-ленинизм, КПК, идеи Мао Цзэдуна, теория Дэн Сяопина, “три представительства", "научная концепция развития", "социализм с китайской спецификой”, “социализм с китайской спецификой в новую эпоху”, посткоммунизм, постмарксизм, постмаоизм

Стаття надійшла до редакиії 27.04.2020 